Original Research Paper

\title{
Design Maximum Power Point Tracking (MPPT) on Photovoltaic Panels using Fuzzy Logic Method
}

\author{
${ }^{1}$ Ahmad Faizal, ${ }^{1}$ Sutoyo, ${ }^{1}$ Mulyono, ${ }^{2}$ Rado Yendra and ${ }^{3}$ Ahmad Fudholi \\ ${ }^{I}$ Department of Electrical Engineering, Faculty of Science and Technology, \\ Universitas Islam Negeri Sultan Syarif Kasim, (UIN Suska) 28293, Pekanbaru, Riau, Indonesia \\ ${ }^{2}$ Department of Mathematics, Faculty of Science and Technology, \\ Universitas Islam Negeri Sultan Syarif Kasim, (UIN Suska) 28293, Pekanbaru, Riau, Indonesia \\ ${ }^{3}$ Solar Energy Research Institute, Universiti Kebangsaan Malaysia, 43600 Bangi Selangor, Malaysia
}

Article history

Received: 16-06-2016

Revised: 19-07-2016

Accepted: 04-08-2016

Corresponding Author: Ahmad Fudholi

Solar Energy Research Institute, Universiti

Kebangsaan Malaysia, 43600

Bangi Selangor, Malaysia

Email: a.fudholi@gmail.com

\begin{abstract}
Solar energy is a clean energy, renewable, and available for the long term. The tool used to convert the energy generated from the intensity of sunlight into electricity is photovoltaic panels. However, due to the high cost and low efficiency, the use of the energy is still kind small compared to other types of energy sources. Thus, the need for an effective and flexible models, which resemble the characteristics of the actual photovoltaic (PV), so that we can perform simple manipulation of some data to figure out how to get the maximum performance possible. The characteristic of the solar panel output is specific and non-linear, it depend on the solar irradiation and the temperature of the solar panel. Because of it, it makes us difficult to get the Maximum Power Point (or abbreviated MPP) of the solar panels. Approach: Therefore, to solve these problems required the modeling of the solar panel for design and simulate the algorithms of Maximum Power Point Tracking (MPPT) to maintain the working point of solar panels fixed on the MPP. Overall, the designed system results carried are running well. The increase in the average value of the output voltage by $17 \%$, from an average of $11.6 \mathrm{~V}$ before installation into $13.94 \mathrm{~V}$ after installation MPPT system. It also occurs in output power with an increase of $28 \%$, from an average of $35.13 \mathrm{~W}$ before installing system MPPT into 48.9 W after installation MPPT system. The temperature effect on module voltage and output power before and after installation of the MPPT system that after the installation of the MPPT system, the voltage output of photovoltaic modules can be maintained around the desired maximum value that's equal to $12 \mathrm{~V}$. But there was a drop in output power value compared to the prior installation MPPT system. This is caused by the output current value that cannot accommodate the value of the output voltage. So that the value of the output current is enough to produce the maximum output power is needed quantities corresponding load.
\end{abstract}

Keywords: Solar panel, MPPT, Fuzzy logic method, Buck-boost DC-DC converter

\section{Introduction}

Energy is required in almost all aspect of everyday life (Sopian et al., 2009a). Depleting of fossil and gas reserves, combined with the growing concerns of global warming, has necessitated an urgent search for alternative energy sources to cater to the present day demands (Sopian et al., 2009b). Demand for electrical energy from time to time continue to increase. Meanwhile, the availability of the power supply that comes from existing power plants are not enough to supply the need that keep growing. Therefore, the need for the development of renewable sources of the electrical energy as an alternative source of energy. Renewable energy can be generally defined as energy derived from natural sources that exist around humans such as solar, wind, wave, and geothermal. As one of the energy sources that are renewable, sunlight (solar energy) it is appropriate to be 
one of the alternative electrical energy sources that can be used and becoming increasingly attractive. Solar energy is a clean energy, renewable, and available for the long term of renewable energy. The use of non-renewable fuels, such as fossil fuel has many side effects. Their combustion products produce global warning, acid rain and pollution (Fudholi et al., 2016a; 2016b; Fudholi et al., 2015a; 2015b; Fudholi et al., 2014a; Fudholi et al., 2010).

The sustainable energy such as solar energy has been identified as one of the promising source of energy to replace the dependency on fossil fuels. Solar energy can play vital role in clean and sustainable energy sources (Fudholi et al., 2015c). Solar energy is a clean energy which has the potential to meet a significant proportional of the world's energy needs (Fudholi et al., 2014b; 2014c). It can be broadly classified into two systems; thermal energy system which converts solar energy into thermal energy, and photovoltaic (PV) energy system which converts solar energy into electrical energy (Ibrahim et al., 2014; Fudholi et al., 2013a; 2013b).

The tools used to convert the energy generated from the intensity of solar into electricity is photovoltaic panels/solar panels. Energy from solar panels offer several advantages, such as little maintenance and no environmental pollution. Recently, the solar panels are used in many applications, such as for charging batteries, solar power generation, solar hybrid vehicles and solar power satellites. However, due to the high cost and low efficiency, the use of the energy is still kind small compared to other types of energy sources. Thus, need for an effective and flexible models, which resemble the characteristics of the actual PV, so that we can perform simple manipulation of some data to figure out how to get the maximum performance possible. The use of this simple model can provide enough accuracy to analyze the behavior of PVs and has been shown to be effective in many cases.

The solar panel featuring the basis of the power conversion unit of solar power generation systems. The output characteristics of the solar panels is specific, depending on solar radiation and temperature of the PVs. Because solar panels have non-linear characteristics, it makes us difficult to get the Maximum Power Point (or abbreviated MPP) of the solar panels. Therefore, to solve these problems required the modeling of the solar panel for design and simulate the algorithms of Maximum Power Point Tracking (MPPT) to maintain the working point of solar panels fixed on the MPP.

In this study, used fuzzy logic method. Fuzzy Logic method used to find the MPP of the solar panels because fuzzy logic has the advantage that it is robust, and relatively simple to design it (Bendib et al., 2014). As a support for the MPPT system, used buck-boost DC-DC converter as a regulator of the output voltage from the solar panel in order to force the solar panel obtain maximum power at changing of irradiation level.

\section{Materials and Methods}

The PV module that used is BPSX60 with a maximum output power is 60 Watt. Therefore, the PV model is built based on the specifications of the PV module. BPSX60 photovolatic module parameters are shown in Table 1 at the STC.

The stages of this study is shown in Fig. 1, flow chart for the following studies.

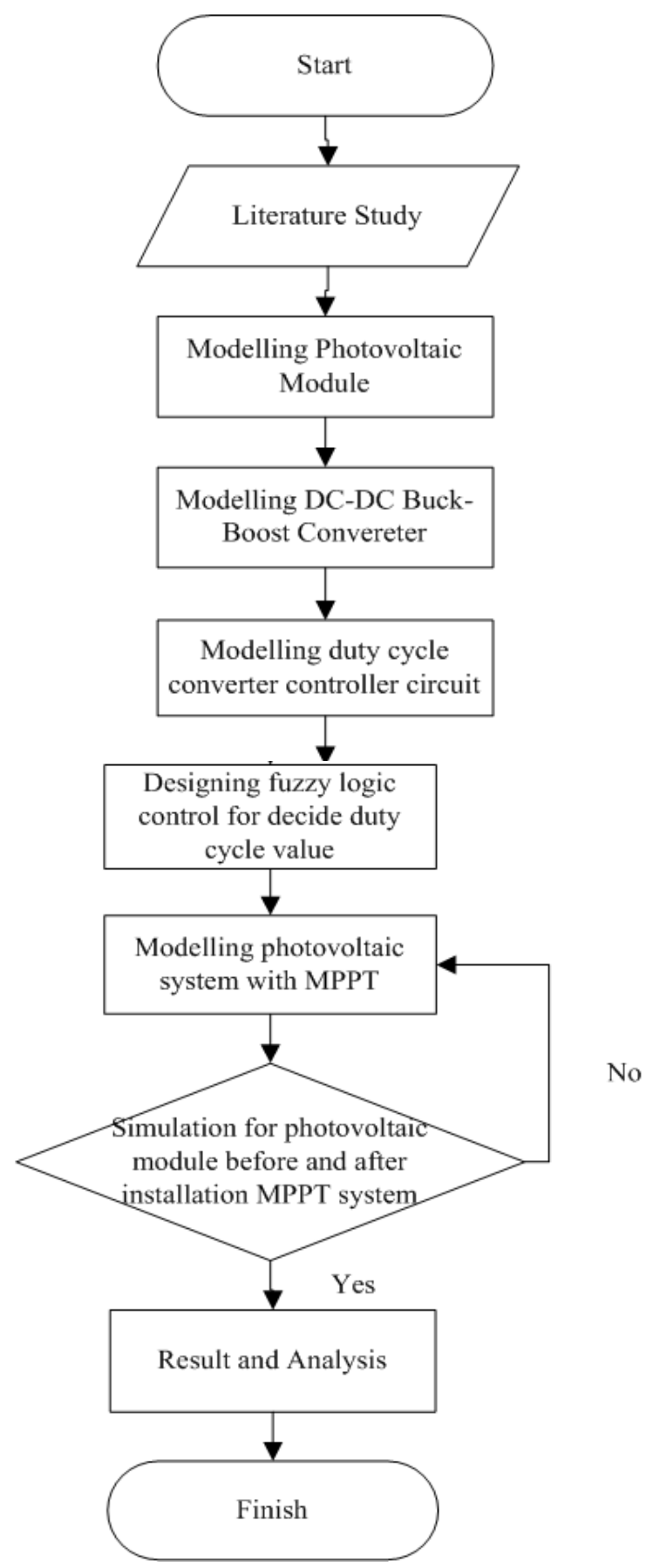

Fig. 1. Study progress flow chart 


\section{Modelling PV Module}

Mathematical modeling in the PV refers to the modeling equation PVs. However, in order to generate enough energy to meet the needs of the load in generally, the energy generated by the PVs is very small. Therefore, it developed into PV modules, the module that consisting of multiple cells so that the equations used refer to the following equation (Nema et al., 2010):

$$
I=n_{p} I_{p h}-n_{p} I_{s}\left(\exp \frac{q V}{(N K T) n_{s}}-1\right)
$$

The final model of the PV module shown in Fig. 2. The input of this model is the working temperature of the module and irradiation.

\section{Modelling Buck-Boost Converter}

From what has been described previously on the circuit and mathematical model of the buck-boost converter, as shown in Fig. 3. Buck-boost converter can be modeled in MATLAB/Simulink. In MATLAB/Simulink, the components of buck-boost converter are available such as inductors, capacitors, diodes, MOSFET and resistors.

In designing a buck-boost converter, it needed parameters to determine the resistors, inductance and capacitors value to be used. These parameters are compatible to the specifications of the photovoltaic module. Buck-boost converter that is modeled is a converter that can raise or lower the input voltage from 5-21 to $12 \mathrm{~V}$. Using the equations described previously, can determined value of the components of a buck-boost converter.

For more details, the parameters of the buck-boost converter as shown in Table 2.
Determining the value of inductance and capacitance values in the model of the buck-boost converter are considered from the transient response and ripple generated by the circuit through the simulation. Table 3 shows the value of each variable remains contained in the buck-boost converter is used.

Table 1. Specification of BPSX60 solar panel

\begin{tabular}{ll}
\hline Specification of solar panel & \\
\hline Ideality diode factor of PN junction $(\mathrm{N})$ & 1.177 \\
Band gap energy $(\mathrm{Eg})$ & $1.12 \mathrm{eV}$ \\
Number of parallel-connected modules $\left(\mathrm{n}_{\mathrm{p}}\right)$ & 1 \\
Number of series-connected modules $\left(\mathrm{n}_{\mathrm{s}}\right)$ & 36 \\
Maximum power at STC $\left(\mathrm{P}_{\mathrm{MAX}}\right)$ & $60 \mathrm{~W}$ \\
Voltage at the MPP $\left(\mathrm{V}_{\mathrm{MAX}}\right)$ & $16.8 \mathrm{~V}$ \\
Current at the MPP $\left(\mathrm{I}_{\mathrm{MAX}}\right)$ & $3.56 \mathrm{~A}$ \\
Nominal Operating Cell Temperature (NOTC) & $47^{\circ} \mathrm{C}$ \\
Short-circuit current at STC $\left(\mathrm{I}_{\mathrm{SC}}\right)$ & $3.87 \mathrm{~A}$ \\
Open-circuit voltage at STC $\left(\mathrm{V}_{\mathrm{OC}}\right)$ & $21.0 \mathrm{~V}$ \\
$\mathrm{~V}_{\mathrm{OC}}$ temperature coefficient $(\mathrm{KV})$ & $-80 \mathrm{mV} /{ }^{\circ} \mathrm{C}$ \\
$\mathrm{I}_{\mathrm{SC}}$ temperature coefficient $(\mathrm{Ki})$ & $0.065 \% /{ }^{\circ} \mathrm{C}$ \\
\hline
\end{tabular}

Table 2. Buck-boost converter variable

\begin{tabular}{ll}
\hline Variable & Value \\
\hline Input voltage $\left(\mathrm{V}_{\text {in }}\right)$ & $5-21 \mathrm{~V}$ \\
Output voltage $\left(\mathrm{V}_{\text {out }}\right)$ & $12 \mathrm{~V}$ \\
Maximum power $(\mathrm{P})$ & $60 \mathrm{~W}$ \\
Frekuency $(\mathrm{fs})$ & $5 \mathrm{kHz}$ \\
Ripple output voltage & $1 \%$ \\
Ripple output current & $5 \%$ \\
\hline
\end{tabular}

Table 3. Buck-boost converter variable

\begin{tabular}{ll}
\hline Variable & Value \\
\hline $\mathrm{L}$ & $6.5 \mathrm{mH}$ \\
$\mathrm{C}$ & $1000 \mu \mathrm{F}$ \\
\hline
\end{tabular}

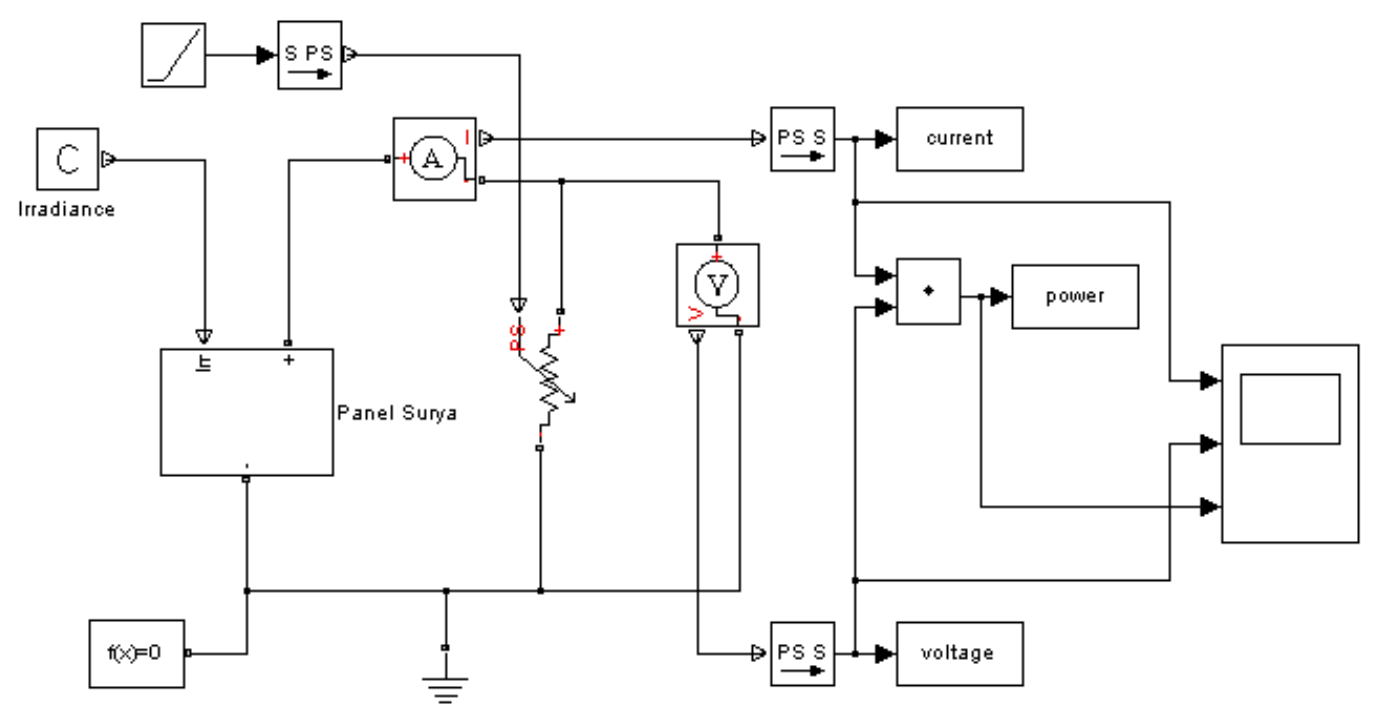

Fig. 2. Solar panel modelling block 


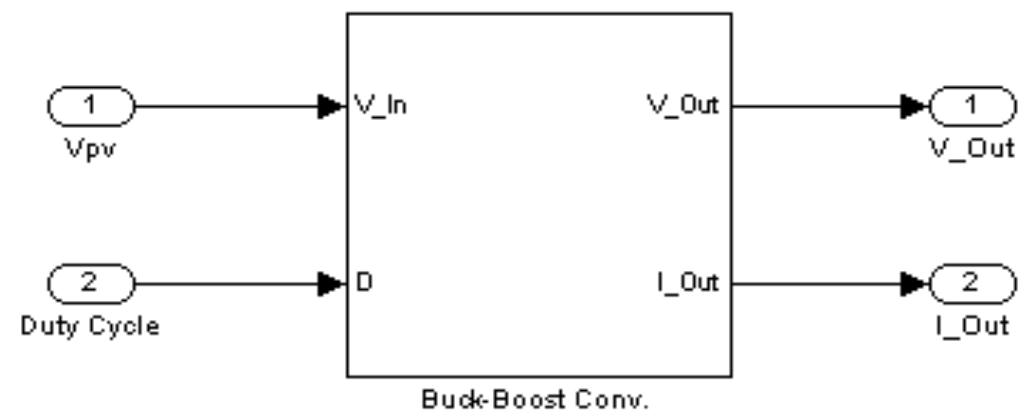

Fig. 3. Buck-boost converter subsystem

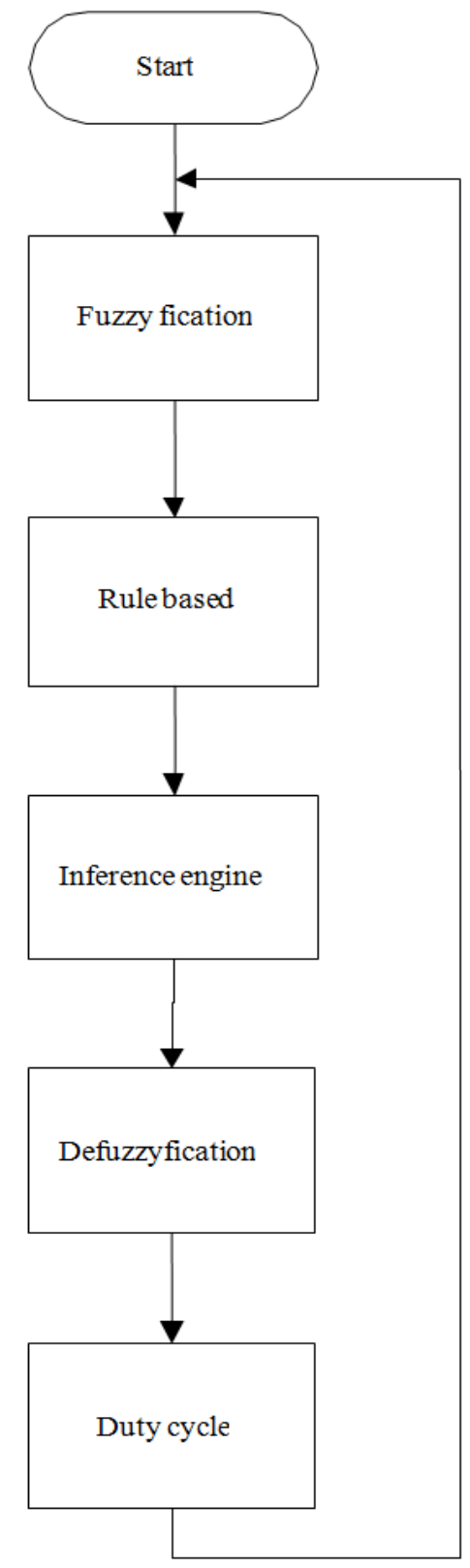

Fig. 4. Flowchart for fuzzy logic control design

\section{Modelling Duty Cycle Converter Controller Circuit}

The circuit block of a PWM signal builder is built to generate the required PWM signal for the buckboost converter. The output of the PWM block is the high and low conditions that have a certain proportion of each period.

\section{Design Fuzzy Logic Control for Decide Duty Cycle Value}

The PV voltage (VPV) on the buck-boost converter circuit above is made to be controlled according to the particular set point value given. Fuzzy logic is used to control the voltage value. Variables that affect VPV is the duty cycle. Therefore, the fuzzy logic output subsystem with a buck-boost converter subsystem is the value of duty cycle, D.

Design of fuzzy logic controller in detail can be shown by Fig. 4, which consists of the design process from the Fuzzy Inference System.

Fuzzy logic control used is Mamdani fuzzy rule based to find the MPP. PWM setting mechanism serves to raise and lower the output voltage of the DC-DC converter.

In designing this study, input of fuzzy logic control is $V_{P V}$ and $I_{P V}$, set between $0-60 V_{P V}$ and $I_{P V}$ is set in the range of $0-10$.

\section{Results and Discussion}

This simulation was conducted to determine the characteristics of the models that have been made. With the characteristics of I-V and P-V it can be seen that the model has been made in accordance with the theory or not. Figure 5-7 shows the simulation result of $\mathrm{I}-\mathrm{V}$ characteristic of PV module for irradiation of 1000, 750 and $500 \mathrm{~W} / \mathrm{m}^{2}$, respectively. Figure $8-10$ shows the simulation result of $\mathrm{P}-\mathrm{V}$ characteristic of $\mathrm{PV}$ module for irradiation of 1000,750 and $500 \mathrm{~W} / \mathrm{m}^{2}$, respectively. Figure11-13 shows the simulation result of $\mathrm{I}-\mathrm{V}$ characteristic of PV module for temperature of 25, 50 and $75^{\circ} \mathrm{C}$, respectively. Figure $14-16$ shows the simulation result of $\mathrm{P}-\mathrm{V}$ characteristic of $\mathrm{PV}$ module for temperature of 25,50 and $75^{\circ} \mathrm{C}$, respectively. 


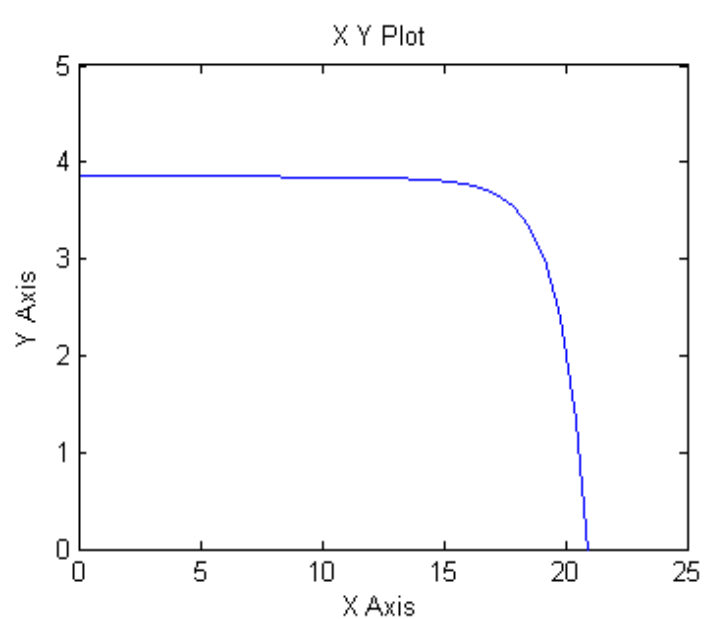

Fig. 5. I-V characteristic for PV module simulation result for $1000 \mathrm{~W} / \mathrm{m}^{2}$

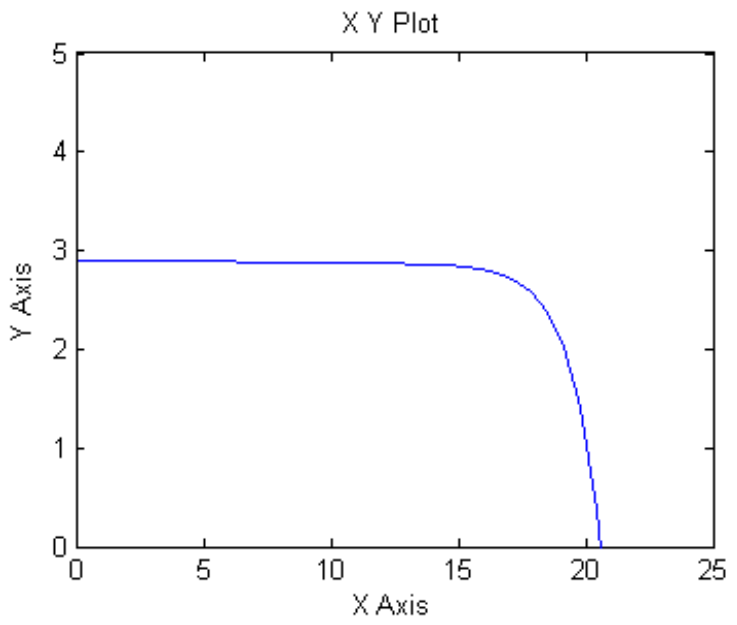

Fig. 6. I-V characteristic for PV module simulation result for $750 \mathrm{~W} / \mathrm{m}^{2}$

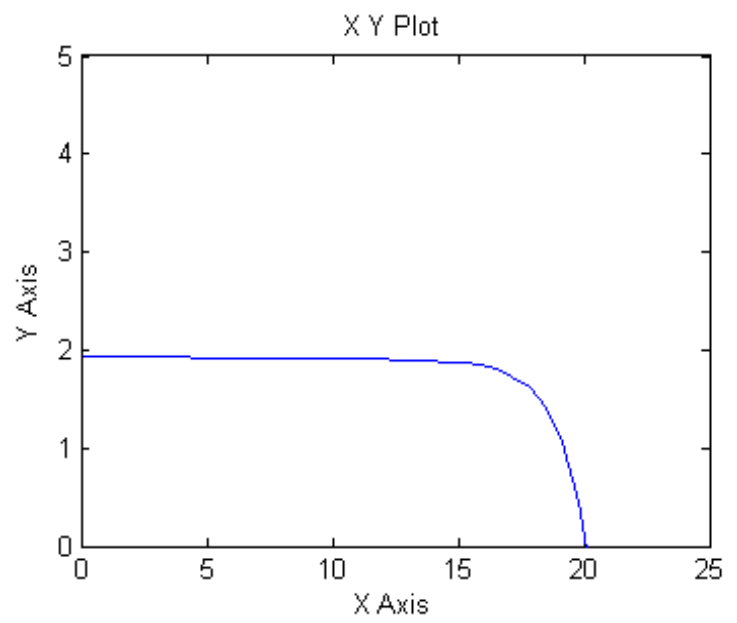

Fig. 7. I-V characteristic for PV module simulation result for $500 \mathrm{~W} / \mathrm{m}^{2}$

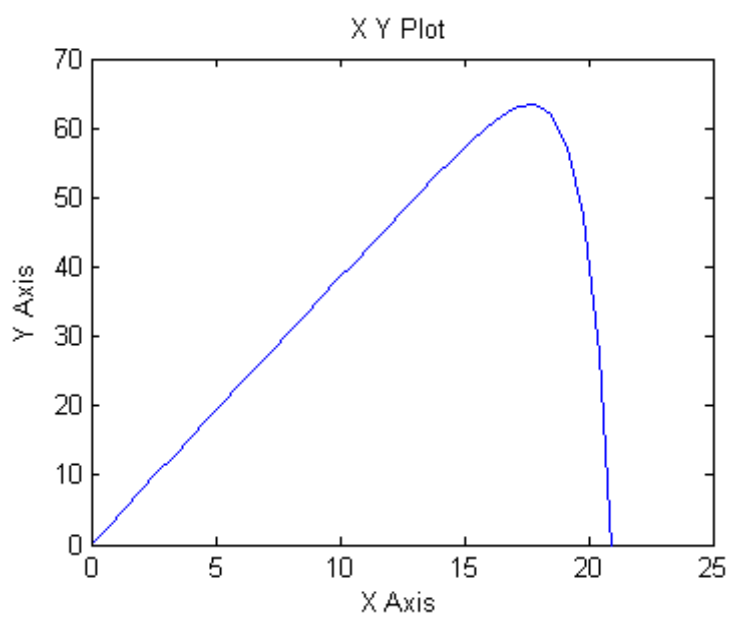

Fig. 8. P-V characteristic for PV module simulation result for $1000 \mathrm{~W} / \mathrm{m}^{2}$

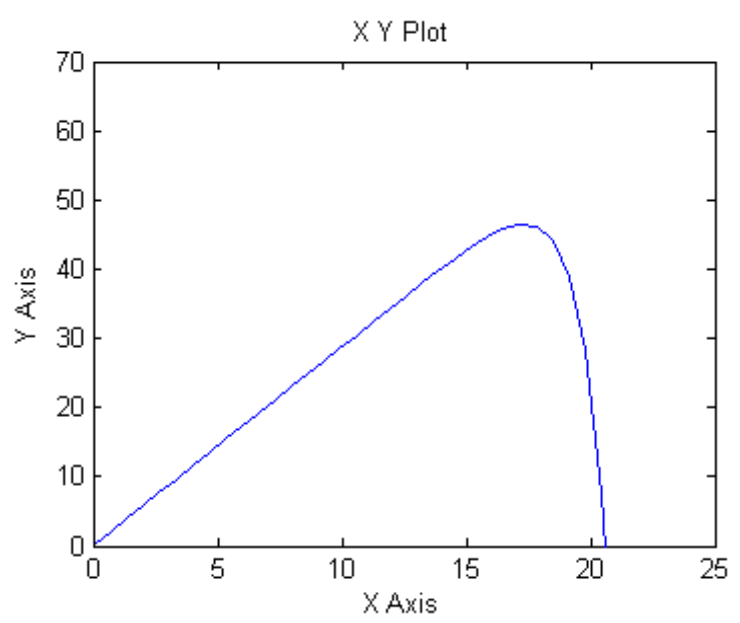

Fig. 9. P-V characteristic for PV module simulation result for $750 \mathrm{~W} / \mathrm{m}^{2}$

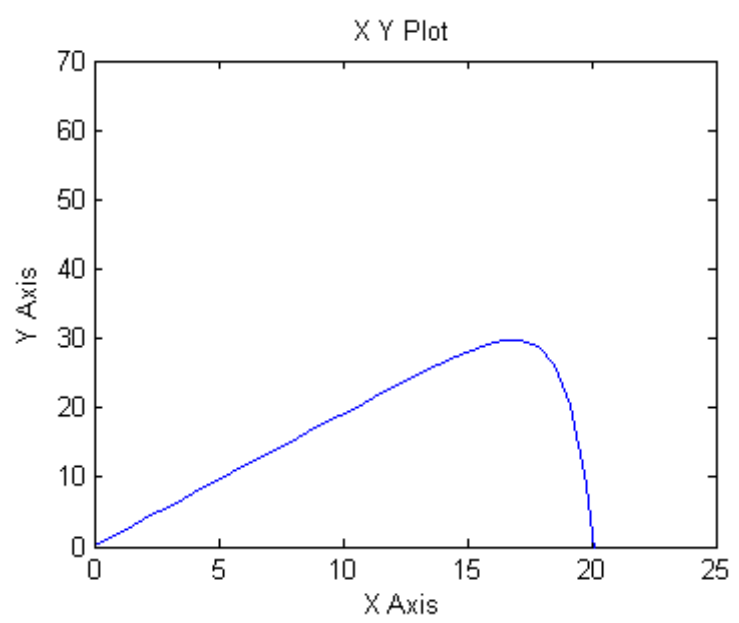

Fig. 10. P-V characteristic for PV module simulation result for $500 \mathrm{~W} / \mathrm{m}^{2}$ 


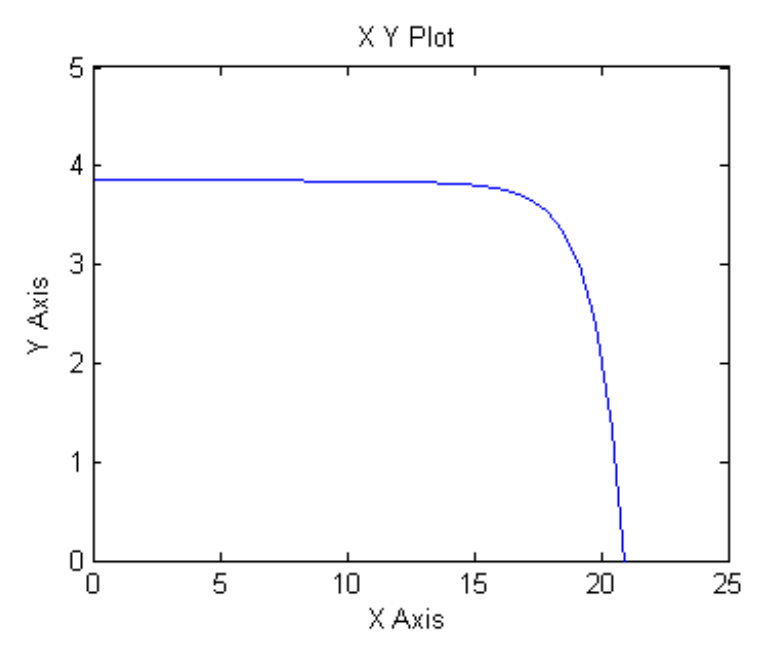

Fig. 11. I-V characteristic for PV module simulation result for $25^{\circ} \mathrm{C}$

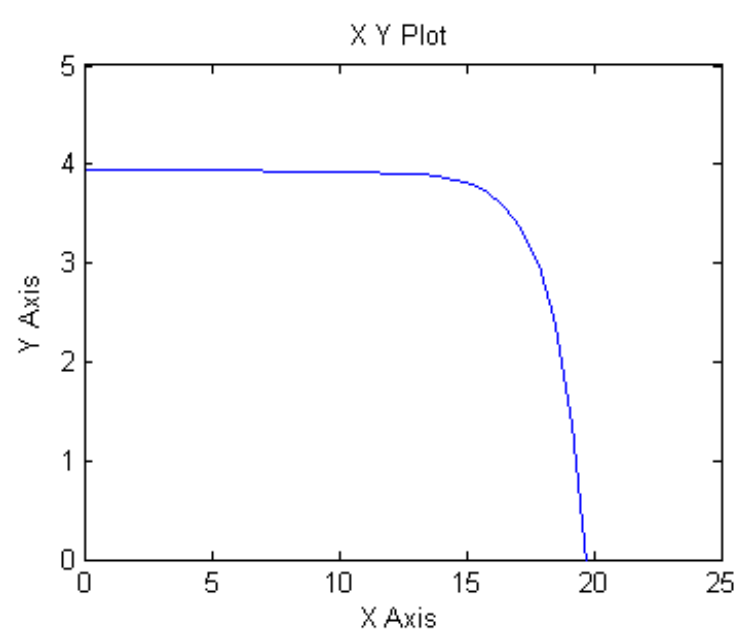

Fig. 12. I-V characteristic for PV module simulation result for $50^{\circ} \mathrm{C}$

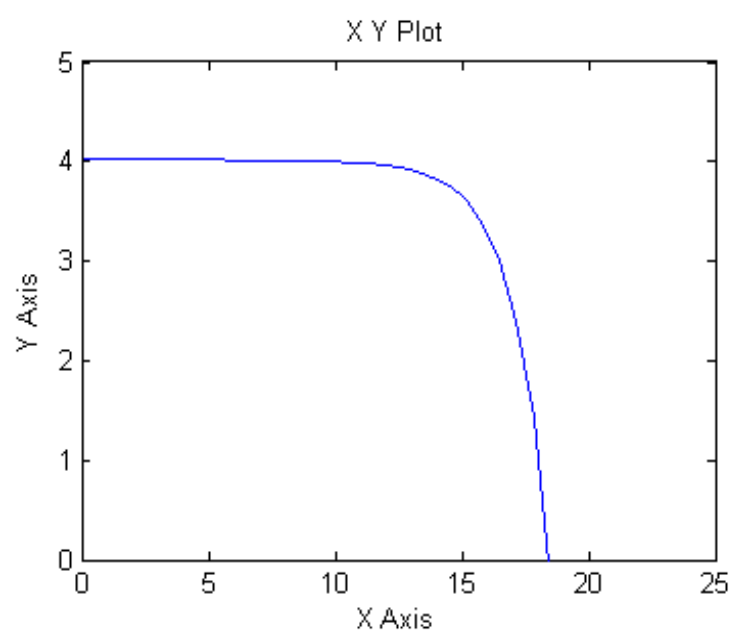

Fig. 13. I-V characteristic for PV module simulation result for $75^{\circ} \mathrm{C}$

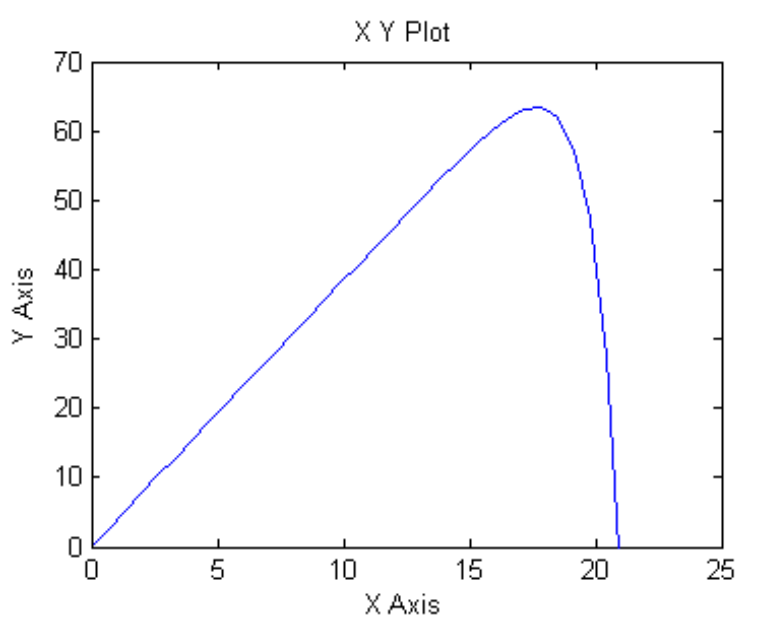

Fig. 14. P-V characteristic for PV module simulation result for $25^{\circ} \mathrm{C}$

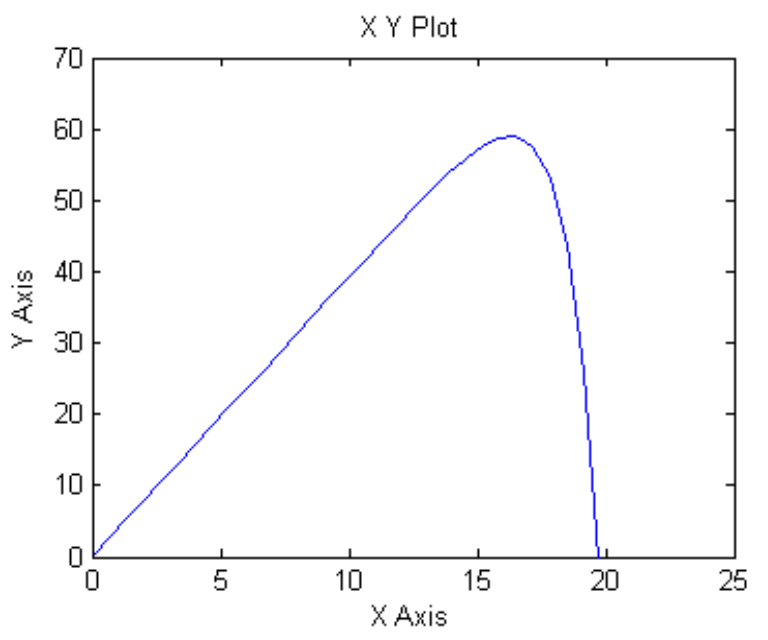

Fig. 15. P-V characteristic for PV module simulation result for $50^{\circ} \mathrm{C}$

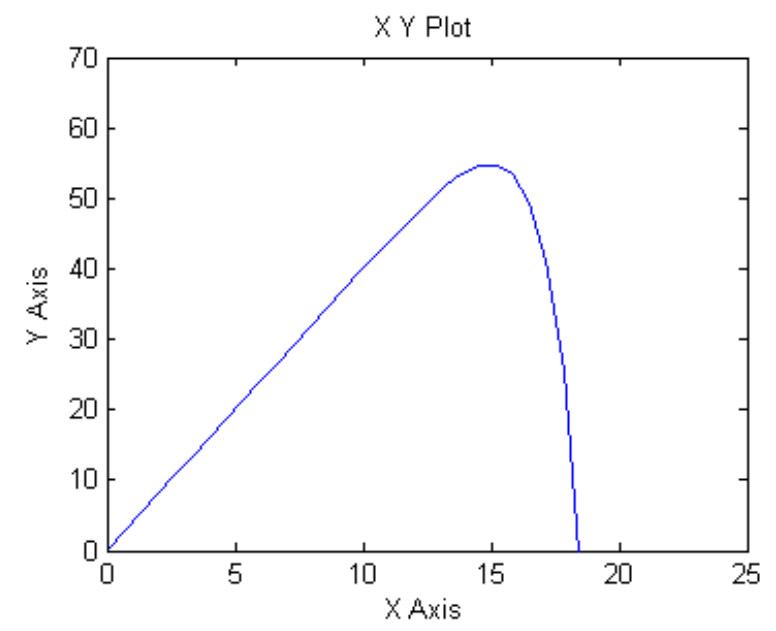

Fig. 16. P-V characteristic for PV module simulation result for $75^{\circ} \mathrm{C}$ 

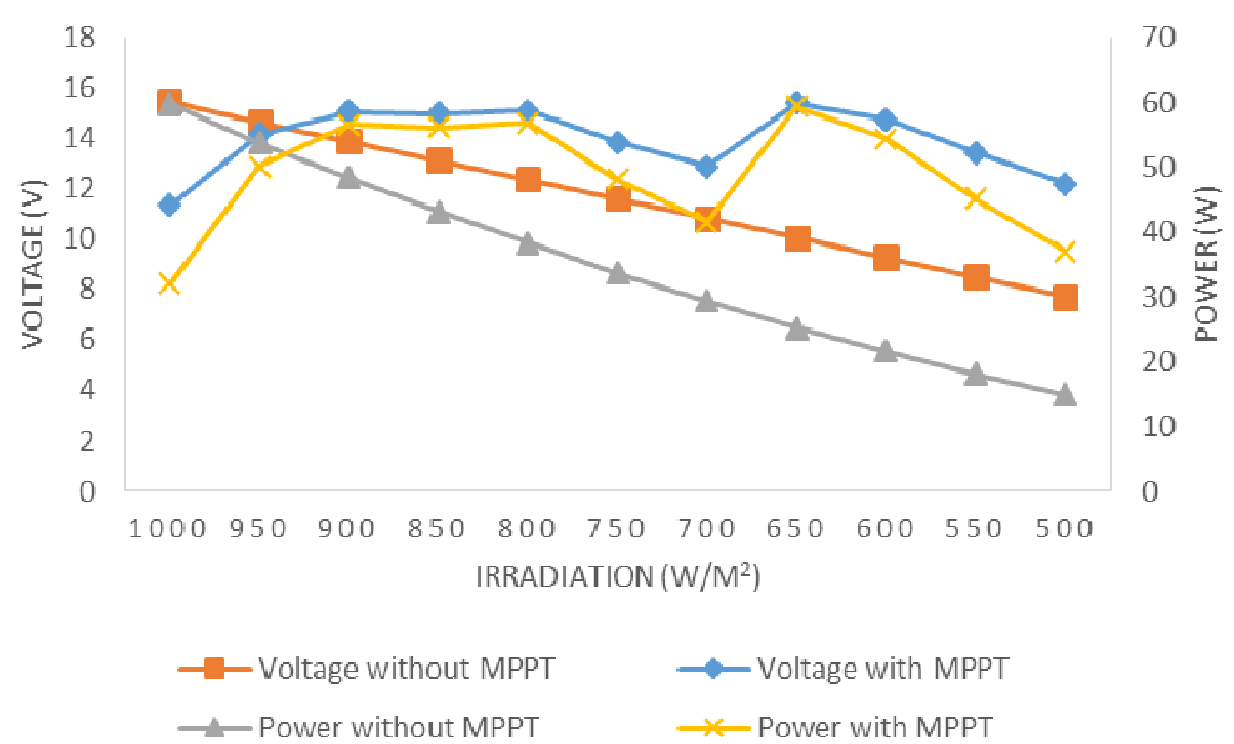

Fig. 17. Irradiation effect on module voltage and output power before and after installation of the MPPT system

Table 4. Simulation result before installation MPPT system with module temperatur variations

\begin{tabular}{llllll}
\hline $\mathrm{R}(\Omega)$ & Irr. $\left(\mathrm{W} / \mathrm{m}^{2}\right)$ & $\mathrm{T}\left({ }^{\circ} \mathrm{C}\right)$ & $\mathrm{V}_{\text {out }}(\mathrm{V})$ & $\mathrm{I}_{\text {out }}(\mathrm{A})$ & $\mathrm{P}_{\text {out }}(\mathrm{W})$ \\
\hline 4 & 1000 & 25 & 15.39 & 3.85 & 59.22 \\
4 & 1000 & 30 & 15.41 & 3.85 & 59.39 \\
4 & 1000 & 35 & 15.43 & 3.86 & 59.53 \\
4 & 1000 & 40 & 15.44 & 3.86 & 59.61 \\
4 & 1000 & 45 & 15.45 & 3.86 & 59.68 \\
4 & 1000 & 50 & 15.46 & 3.87 & 59.75 \\
4 & 1000 & 55 & 15.47 & 3.87 & 59.81 \\
4 & 1000 & 60 & 15.47 & 3.87 & 59.82 \\
4 & 1000 & 65 & 15.47 & 3.87 & 59.84 \\
4 & 1000 & 70 & 15.47 & 3.87 & 59.84 \\
4 & 1000 & 75 & 15.47 & 3.87 & 59.85 \\
\hline
\end{tabular}

Table 5. Simulation result before installation MPPT system with irradiation variations

\begin{tabular}{llllll}
\hline $\mathrm{R}(\Omega)$ & Irr. $\left(\mathrm{W} / \mathrm{m}^{2}\right)$ & $\mathrm{T}\left({ }^{\circ} \mathrm{C}\right)$ & $\mathrm{V}_{\text {out }}(\mathrm{V})$ & $\mathrm{I}_{\text {out }}(\mathrm{A})$ & $\mathrm{P}_{\text {out }}(\mathrm{W})$ \\
\hline 4 & 1000 & 25 & 15.47 & 3.87 & 59.85 \\
4 & 950 & 25 & 14.66 & 3.67 & 53.73 \\
4 & 900 & 25 & 13.91 & 3.48 & 48.37 \\
4 & 850 & 25 & 13.15 & 3.29 & 43.22 \\
4 & 800 & 25 & 12.38 & 3.10 & 38.32 \\
4 & 750 & 25 & 11.61 & 2.90 & 33.69 \\
4 & 700 & 25 & 10.83 & 2.71 & 29.34 \\
4 & 650 & 25 & 10.06 & 2.52 & 25.30 \\
4 & 600 & 25 & 9.29 & 2.32 & 21.57 \\
4 & 550 & 25 & 8.51 & 2.13 & 18.12 \\
4 & 500 & 25 & 7.74 & 1.94 & 14.98 \\
\hline
\end{tabular}

The simulation photovoltaic module before installing MPPT system is divided into two, namely simulated photovoltaic module before installing MPPT system with variation of temperature modules and simulated photovoltaic module before installing the MPPT system with variations of solar irradiation.
Table 6. Simulation result after installation MPPT system with module temperatur variations

\begin{tabular}{llllll}
\hline $\mathrm{R}(\Omega)$ & Irr. $\left(\mathrm{W} / \mathrm{m}^{2}\right)$ & $\mathrm{T}\left({ }^{\circ} \mathrm{C}\right)$ & $\mathrm{V}_{\text {out }}(\mathrm{V})$ & $\mathrm{I}_{\text {out }}(\mathrm{A})$ & $\mathrm{P}_{\text {out }}(\mathrm{W})$ \\
\hline 4 & 1000 & 25 & 11.35 & 2.83 & 32.12 \\
4 & 1000 & 30 & 11.27 & 2.81 & 31.67 \\
4 & 1000 & 35 & 11.19 & 2.79 & 31.22 \\
4 & 1000 & 40 & 11.11 & 2.77 & 30.77 \\
4 & 1000 & 45 & 11.11 & 2.77 & 30.77 \\
4 & 1000 & 50 & 11.08 & 2.77 & 30.69 \\
4 & 1000 & 55 & 11.04 & 2.76 & 30.47 \\
4 & 1000 & 60 & 11.04 & 2.76 & 30.47 \\
4 & 1000 & 65 & 11.04 & 2.77 & 30.58 \\
4 & 1000 & 70 & 11.06 & 2.77 & 30.64 \\
4 & 1000 & 75 & 11.05 & 2.76 & 30.50 \\
\hline
\end{tabular}

Table 7. Simulation result after installation MPPT system with irradiation variations

\begin{tabular}{llllll}
\hline $\mathrm{R}(\Omega)$ & Irr. $\left(\mathrm{W} / \mathrm{m}^{2}\right)$ & $\mathrm{T}\left({ }^{\circ} \mathrm{C}\right)$ & $\mathrm{V}_{\text {out }}(\mathrm{V})$ & $\mathrm{I}_{\text {out }}(\mathrm{A})$ & $\mathrm{P}_{\text {out }}(\mathrm{W})$ \\
\hline 4 & 1000 & 25 & 11.35 & 2.83 & 32.12 \\
4 & 950 & 25 & 14.17 & 3.54 & 50.16 \\
4 & 900 & 25 & 15.06 & 3.76 & 56.63 \\
4 & 850 & 25 & 15.00 & 3.75 & 56.25 \\
4 & 800 & 25 & 15.09 & 3.77 & 56.89 \\
4 & 750 & 25 & 13.88 & 3.47 & 48.16 \\
4 & 700 & 25 & 12.90 & 3.22 & 41.54 \\
4 & 650 & 25 & 15.43 & 3.85 & 59.41 \\
4 & 600 & 25 & 14.76 & 3.69 & 54.46 \\
4 & 550 & 25 & 13.46 & 3.36 & 45.23 \\
4 & 500 & 25 & 12.20 & 3.04 & 37.09 \\
\hline
\end{tabular}

The simulation results before the installation of MPPT system with temperature variation and solar irradiation variation can be seen in Table 4 and 5 .

While the results of the simulation of photovoltaic modules after installation MPPT system with temperature variation and variation of solar irradiation can be seen in Table 6 and 7 . 
By looking at the test results in Table 4, the effect of temperature on the module voltage, current and power generated by the solar panel module is very small. It can be seen from given some temperature variation with constant load and solar irradiation.

While in Table 5 , to see the test results, the effect of solar irradiation on the voltage, current and power generated by the photovoltaic module is very large. The voltage and current output generated very unconstant and getting lower with declining the value of solar irradiation and therefore contributes to the output power continues to decline. It can be seen from some variation of solar irradiation given to the constant load and module temperature. The smaller the value of solar irradiation is given, then the efficiency of photovoltaic modules do the same.

But after the installation of the MPPT system to the same conditions of temperature and solar radiation at the same load, the system can maintain the voltage output of photovoltaic modules in the range of corresponding to the design. The test results after the installation of MPPT system to photovoltaic modules on the $4 \Omega$ load with variations in temperature and solar irradiation module can be seen in Table 6 and 7 .

Reffering to Table 5 and 7 and Fig. 17, it shown the effect of the installation MPPT system to the value of solar irradiation. Voltage and power output of photovoltaic module before installing MPPT system can not maintain the value of its output when the solar irradiation conditions change. But after the installation of MPPT system, voltage and power output of photovoltaic modules can be maintained around the maximum value.

Besides that increase in the average value of the output voltage by $17 \%$, from an average of $11.6 \mathrm{~V}$ before installation into $13.94 \mathrm{~V}$ after installation MPPT system. It also occurs in output power with an increase of $28 \%$, from an average of $35.13 \mathrm{~W}$ before installing system MPPT into $48.9 \mathrm{~W}$ after installation MPPT system.

Overall, the designed system results carried are running well. However, fuzzy logic algorithm that used still can not be perfect. Fuzzy logic algorithm that used can be more leverage by adding the number of membership, as well as other input parameters corresponding to the characteristics of the existing solar panels, as well as the design rules that can be further refined.

Base on conclusion by Bendib et al. (2015) that numerical simulations (using Simulink/Matlab) were carried out for PV systems containing conventional and intellligent fuzzy MPPT controllers, under varying climatic conditions. The obtained simulation results are very promising and prove in general that the fuzzy MPPT controller performances, in terms of stability, precision and speed in the tracking of the MPP are much better than those of the conventional MPPT methods (P\&O and IncCond). On the other hand, Mosal et al. (2012) studied the MPPT by using Model Predictive
Control (MPC) which the algorithm that is used in this modification is perturb and observe algorithm ( $\mathrm{P} \& \mathrm{O})$. They concluded that this modification is applied on the dc-dc multilevel boost converter that is connected to PV modules. This modification improves the response of the system. MLBC extracts the maximum power from PV modules at any level of the irradiation and temperature.

\section{Conclusion}

Based on the analysis and discussion, obtained some conclusions as follows:

- The simulation results show that the characteristics of photovoltaic modules model are made almost match the original

- MPPT system can keep the voltage and power output of photovoltaic modules around its maximum value when the solar irradiation conditions are changed

- An increase in the average value of the output voltage by $17 \%$ from an average of $11.6 \mathrm{~V}$ before fitting the MPPT system becomes $13.94 \mathrm{~V}$ after the installation of the MPPT system during solar irradiation conditions are changed

- There was an increase in power output by $28 \%$, from an average of $35.13 \mathrm{~W}$ before mounting system MPPT to be $48.9 \mathrm{~W}$ after the installation of the MPPT system during solar irradiation conditions are changed

- At the temperature conditions change, the MPPT system can maintain the output voltage of photovoltaic modules around a desired maximum value is equal to $12 \mathrm{~V}$

- The output power of the system is still not maximized because of the load current is unable to accommodate the output voltage. Required appropriate load so that the current generated is sufficient to maximize the power generated

\section{Acknowledgement}

The authors would like to thank the Faculty of Science and Technology, Universitas Islam Negeri Sultan Syarif Kasim (UIN Suska) Pekanbaru, Riau, Indonesia for support and UKM for funding (DLP-2015-005).

\section{Author's Contributions}

Ahmad Faizal: Design concept, data interpretation, and paper writing of the paper.

Sutoyo: Execution of simulations modelling buckboost converter and modelling PV module.

Mulyono: Execution of modelling duty cycle converter controller circuit and fuzzy logic control for decide duty cycle value. 
Rado Yendra: Revise and improve the final drafts of the paper. Also, contribute to data interpretation and the writing of the paper.

Ahmad Fudholi: Critical review of the scientific content of the paper. Revise, improve and editing the final drafts of the paper. In addition, contribute to the writing of the paper.

\section{Ethics}

This article is original and contains unpublished material. The corresponding author confirms that all of the other authors have read and approved the manuscript and no ethical issues involved.

\section{References}

Bendib, B., H. Belmili and F. Krim, 2015. A survey of the most used MPPT methods: Conventional and advanced algorithms applied for photovoltaic systems. Renewable Sustainable Energy Rev., 45: 637-648. DOI: 10.1016/j.rser.2015.02.009

Bendib, B., F. Krim, H. Belmili, M.F. Almi and S. Boulouma, 2014. Advanced fuzzy MPPT controller for a stand-alone PV system. Energy Proc., 50: 383-392. DOI: 10.1016/j.egypro.2014.06.046

Fudholi, A., S. Mat, D.F. Basri, Ruslan and K. Sopian, 2016a. Performances analysis of greenhouse solar dryer with heat exchanger. Contemporary Eng. Sci., 9: 135-144. DOI: 10.12988/ces.2016.512322

Fudholi, A., R. Yendra, D.F. Basri, M.H. Ruslan and K. Sopian, 2016b. Energy and exergy analysis of hybrid solar drying system. Contemporary Eng. Sci., 9: 215-223. DOI: 10.12988/ces.2016.512323

Fudholi, A., K. Sopian, M. Gabbasa, B. Bakhtyar and M. Yahya et al., 2015a. Techno-economic of solar drying systems with water based solar collectors in Malaysia: A review. Renewable Sustainable Energy Rev., 51: 809-820. DOI: 10.1016/j.rser.2015.06.059

Fudholi, A., K. Sopian, B. Bakhtyar, M. Gabbasa and M.Y. Othman et al., 2015b. Review of solar drying systems with air based solar collectors in Malaysia. Renewable Sustainable Energy Rev., 51: 1191-1204. DOI: 10.1016/j.rser.2015.07.026

Fudholi, A., K. Sopian, M.A. Alghoul, M.H. Ruslan and M.Y. Othman, 2015c. Performances and improvement potential of solar drying system for palm oil fronds. Renewable Energy, 78: 561-565. DOI: 10.1016/j.renene.2015.01.050

Fudholi, A., K. Sopian, M.H. Yazdi, M.H., Ruslan and M. Gabbasa et al., 2014a. Performance analysis of solar drying system for red chili. Solar Energy, 99: 47-54. DOI: 10.1016/j.solener.2013.10.019
Fudholi, A., K. Sopian, M.H. Yazdi, M.H. Ruslan and A. Ibrahim et al., 2014b. Performance analysis of Photovoltaic Thermal (PVT) water collectors. Energy Conv. Manage., 78:641-651. DOI: 10.1016/j.enconman.2013.11.017

Fudholi, A., K. Sopian, M.Y. Othman and M.H. Ruslan, 2014c. Energy and exergy analyses of solar drying system of red seaweed. Energy Build., 68: 121-129. DOI: 10.1016/j.enbuild.2013.07.072

Fudholi, A., K. Sopian, M.Y. Othman, M.H. Ruslan and B. Bakhtyar, 2013a. Energy analysis and improvement potential of finned double-pass solar collector. Energy Conv. Manage., 75: 234-240. DOI: 10.1016/j.enconman.2013.06.021

Fudholi, A., K. Sopian, M.H. Ruslan and M.Y. Othman, 2013b. Performance and cost benefit analysis of double-pass solar collector with and without fins. Energy Conv. Manage., 76: 8-19. DOI: 10.1016/j.enconman.2013.07.015

Fudholi, A., K. Sopian, M.H. Ruslan, M.A. Alghoul and M.Y. Sulaiman, 2010. Review of solar dryers for agricultural and marine products. Renewable Sustainable Energy Rev., 14: 1-30. DOI: 10.1016/j.rser.2009.07.032

Ibrahim, A., A. Fudholi, K. Sopian, M.Y. Othman and M.H. Ruslan, 2014. Efficiencies and improvement potential of Building Integrated Photovoltaic Thermal (BIPVT) system. Energy Conv. Manage., 77: 527-534. DOI: 10.1016/j.enconman.2013.10.033

Nema, S., R.K. Nema and G. Agnihotri, 2010. Matlabsimulink based study of photovoltaic cells modules array and their experimental verification. Int. J. Energy Environ., 1: 487-500.

Sopian, K., A. Fudholi, M.H. Ruslan, M.Y. Sulaiman and M.A. Alghoul et al., 2009a. Optimization of a stand-alone wind/PV hybrid system to provide electricity for a household in Malaysia. Proceeding of the 4th IASME/WSEAS International Conference on Energy and Environment, Feb. 24-26, WSEAS Press, Cambridge, UK, pp: 435-438.

Sopian, K., A. Fudholi, M.H. Ruslan, M.Y. Sulaiman and M.A. Alghoul et al., 2009b. Optimization of a stand-alone wind/PV hybrid system to provide electricity for a household in Malaysia. Proceeding of the 4th IASME/WSEAS International Conference on Energy and Environment, Feb. 24-26, WSEAS Press, Cambridge, UK, pp: 431-434.

Mosal, M., H.A. Rubl, M.E. Ahmed and J. Rodriguez, 2012. Modified MPPT with using model predictive control for multilevel boost converter. Proceedings of the 38th Annual Conference on IEEE Industrial Electronics Society, Oct. 25-28, IEEE Xplore Press, Japan, pp: 5080-5085.

DOI: 10.1109/IECON.2012.6389559 